\title{
Electrochemical and Catalytic Properties of oxo-ruthenate(VI) in Aqueous Alkaline Medium
}

\author{
Abdel Ghany F. Shoair ${ }^{1}$ Mai M. A. H. Shanab ${ }^{2}$, Mohamed H. H. Mahmoud ${ }^{3}$ \\ ${ }^{1}$ Department of Science and Technology, University College - Ranyah, Taif University, Saudi Arabia \\ ${ }^{2}$ Department of Chemistry, Sciences \& Humanities Studies College, Hawtat Bani Tamim, Prince \\ Sattam Bin Abdul-Aziz University, Al-Kharj, Saudi Arabia \\ ${ }^{3}$ Department of Chemistry, College of Science, Taif University, P.O. Box 11099, Taif, 21944, Saudi \\ Arabia \\ *E-mail: afshaair@tu.edu.sa
}

doi: $10.20964 / 2021.05 .44$

Received: 4 January 2021 / Accepted: 6 March 2021 / Published: 31 March 2021

\begin{abstract}
The complex $\mathrm{K}_{2}\left[\mathrm{Ru}^{(\mathrm{III})} \mathrm{Cl}_{5}\left(\mathrm{H}_{2} \mathrm{O}\right)\right]$ has been prepared and characterized by different spectroscopic techniques (IR and UV-VIS). The electrochemical properties of this complex were investigated at different $\mathrm{pH}$ 's using Robinson buffer solutions. The cyclic voltammograms exhibited three redox different oxidation and potential peaks due to generation of $\mathrm{Ru}(\mathrm{III}), \mathrm{Ru}(\mathrm{IV}), \mathrm{Ru}(\mathrm{V})$ and $\mathrm{Ru}(\mathrm{VI})$ ions. The catalytic activity of $\mathrm{K}_{2}\left[\mathrm{Ru}^{(\mathrm{III})} \mathrm{Cl}_{5}\left(\mathrm{H}_{2} \mathrm{O}\right)\right]$ towards the hydration of some aromatic and three heterocyclic nitriles to their corresponding amides was investigated with excess of three co-oxidants $\mathrm{K}_{2} \mathrm{~S}_{2} \mathrm{O}_{8}, \mathrm{NaOCl}$ and $\mathrm{KBrO}_{3}$. A number of factors have been investigated and the best yields were obtained with $\mathrm{K}_{2} \mathrm{~S}_{2} \mathrm{O}_{8}$ as a co-oxidant in a $1.0 \mathrm{M} \mathrm{KOH}$ at $80{ }^{\circ} \mathrm{C}$. Both spectroscopic and electrochemical techniques were used to establish the nature of active species in this catalytic reaction and the active catalyst was found to be $\mathrm{K}_{2}\left[\mathrm{Ru}^{(\mathrm{VI})} \mathrm{O}_{3}(\mathrm{OH})_{2}\right]$, as well as to explain the possible reaction mechanism. The suggested mechanism included the coordination of nitrile to ruthenium center followed by liberation of the corresponding amide and the active complex again.
\end{abstract}

Keywords: ruthenium, catalytic hydration, co-oxidant

\section{$\underline{\text { FULL TEXT }}$}

(C) 2021 The Authors. Published by ESG (www.electrochemsci.org). This article is an open access article distributed under the terms and conditions of the Creative Commons Attribution license (http://creativecommons.org/licenses/by/4.0/). 